\title{
ENVIRONMENTAL REGULATION AND INDUSTRIAL PERFORMANCE: AN EMPIRICAL ANALYSIS OF MANUFACTURING INDUSTRY IN CHINA
}

\author{
R.R. YANG, R.Y. LONG, T. YUE \& Y.Y. ZHUANG \\ School of Management, China University of Mining and Technology, China.
}

\begin{abstract}
The impact of environmental regulations on industry performance is a current worldwide concern. There are several different viewpoints on the effects of environmental regulations. Whether environmental regulations could hamper industrial performance is worth to be assessed in China. We use panel data for six samples from manufacturing industry in China from 1996 to 2011 in an empirical analysis of the impact of environmental regulations on industry performance. The results show that environmental regulations have a significant positive relationship with productivity and have a certain role in promoting the performance of manufacturing industries. This leads to a different conclusion from the general point of view, and the Porter Hypothesis is verified to a certain degree.

Keywords: Environmental regulations, industry performance, manufacturing industry, panel data, Porter Hypothesis.
\end{abstract}

\section{INTRODUCTION}

From 2000 to 2011, the economic growth rate in China remained above $8 \%$ and was $7.8 \%$ in 2012, even under the shock of the financial crisis. However, rapid economic growth has caused serious environmental issues that have affected the sustainable social and economic development of the whole country. Since 1970s, China has formulated many environmental policies and regulations to reduce the negative environmental impact of industry [1]. There is now a consensus that environmental regulations play an important role in controlling industrial pollution. A vital question is whether they affect industrial performance and how to balance the relationships between environmental protection, economic development and industrial performance.

Worldwide research into the relationship between environmental regulations and industry performance dates back to the early 1970s and can be summarized in three different views: traditional, modified, and uncertain views. According to the traditional view, implementation of environmental regulations reduces industrial performance because the regulations inevitably lead to additional production costs and consequently increase the burden on enterprises. If the technical level is constant, environmental regulations will inevitably lead to a reduction in productivity [2]. The empirical analysis by Lanoie et al. showed that the contemporaneous impact of environmental regulations on productivity was opposite to the lagged impact [3]. Environmental regulations have a stronger influence on international industries. Stricter environmental policies to reduce emissions have stronger negative effects on industry profits [4]. Empirical estimates by some researchers suggest that environmental regulations have a certain degree of negative impact on industry performance, confirming the traditional view [5-8]. It cannot be denied that any marginal social benefit generated by such regulations might outweigh the marginal private costs. However, under different circumstances, the effects of environmental regulations on an efficient and greener economy can differ [9]. When measuring the effects of environmental regulation on productivity growth, emission reductions should be taken into account [10]. 
According to the modified view, properly designed environmental regulations can stimulate innovation in regulated enterprises, leading to identification cost savings that match or exceed the cost of compliance with environmental regulations and thus boosting industrial performance. Enterprises can also take the lead in adopting environmentally friendly measures, such as the development of clean production technology and environmental product innovations. This can lead to first-mover advantages over other companies. Results for the effect of environmental regulation on productivity using manufacturing data from different countries support the modified view to varying degrees [11-19]. More stringent enforcement of environmental regulations would help to improve productivity growth in China [20]. Environmental regulation has a positive but diminishing impact on investment, especially for small industries. Innovation behavior seems to be mainly correlated with the stringency of environmental policies [21-23].

Since the Porter Hypothesis was proposed, which considers that felicitous environmental regulations may bestir corporations to innovate, to reduce expenses and to improve the quality of products, so environmental regulations will be good for the competitiveness of corporations, a number of studies [24] have tested the hypothesis and explored its validity. Subsequently, some researchers $[25,26]$ estimated the relationship between environmental regulations and industrial performance from different angles using econometrics. They generally found that analysis using either industry- or plant-level data cannot provide evidence to support any of the views, and the impact of environmental regulation on industry performance is ambiguous. Empirical support from Romania showed that environmental stringency does not affect either trade or its components [27]. Study of the $\mathrm{CO}_{2}$ emissions of 30 OECD countries in 1998-2002 showed that environmental regulations caused zero opportunity costs in few countries [28]. An empirical analysis of a county of Jiangsu Province in China showed that the positive effect of regulation on performance is not significant [29]. An empirical analysis of German manufacturing industry revealed neither an improvement nor a loss in overall competitiveness [30]. Environmental regulation has important implications for economic development but the impact varies at different development stages [31]. Investment in proactive environmental management can contribute increased competitiveness [32]. The response of industrial firms in Egypt was limited [33].

Most studies on the effect of environmental regulation on industry performance have been done by foreign researchers. In China, research on the impact of environmental regulations started rather late, and most scholars have focused on how environmental regulations impact industrial competitiveness and technological innovation. Empirical studies on the relationship between environmental regulation and industry performance are still rather scarce. Therefore, the objective of this study was to examine the effect of environmental regulation on industrial performance from an empirical viewpoint, which may contribute to evaluating the effect of implementing environmental regulation policies in China and thus provide a reference for improving and enhancing environmental regulations.

The remainder of the paper is organized as follows. Section 2 describes the methods and data used in our empirical analysis of the effect of environmental regulation on industrial performance. Section 3 describes progress and presents results of the empirical analysis. Section 4 draws conclusions.

\section{EMPIRICAL STUDY}

\subsection{Sample industry selection, relevant variables, and data}

Since 2003, secondary industries in China have been divided into four major categories: mining (B type), manufacturing (C type), electricity, gas and water production and supply (D type), and the building trade (E type). The manufacturing sector includes up to 43 different activities. We select the 
following six major industries in the manufacturing sector as sample industries: manufacture of paper and paper products; processing of petroleum and coking; manufacture of raw chemical materials and chemical products; manufacture of non-metallic mineral products; smelting and pressing of ferrous metals; and smelting and pressing of non-ferrous metals. These six industries consumed 1.59 billion tons of standard coal in 2011 accounting for $74.6 \%$ of the total energy consumption by manufacturing industries in 2001 and $79.2 \%$ in 2011, which represents approximately $45.6 \%$ of the total energy use in China. These six activities are not only high-consumption industries but are also the most polluting industries. They are energy-intensive and an important source of emissions in manufacturing industry. In 2007, the total discharge of industrial wastewater by these six industries reached 10.507 billion tons, representing approximately $58.0 \%$ of total manufacturing emissions, and $\mathrm{SO}_{2}$ emissions accounted for $84.0 \%$ of the manufacturing total. Therefore, our sample industries represent the most energy-intensive manufacturing industries in China.

We used panel data in a fixed effect model to analyze the effect of environmental regulation on industry performance, so industry performance is clearly the dependent variable. Conventionally, industry performance in manufacturing is assessed by measuring the profit ratio of sales (Pro) and overall labor productivity (LP). We selected environmental regulation intensity (ERI) as the variable reflecting environmental regulation. ERI can be operationalized in numerous ways, including pollution abatement expenditure or costs, pollution charges, and environmental management. In many studies, pollution abatement costs are used as the ERI, because many enterprises faced with strict environmental regulations spend more on pollution abatement strategies to reduce pollution. Pollution abatement costs can better reflect the ERI of an industry, which will be enhanced with stricter environmental regulations. Therefore, we chose the running costs for pollution treatment to measure environmental regulations. According to Zhao [34], ERI is the ratio of pollution abatement costs to industrial output multiplied by 1000 . We selected industrial scale (SIZE) and market concentration (CR) as control variables. According to studies of the relationship between industrial scale and profitability in China, we hypothesized that industrial scale may affect the profit margin and productivity of an industry. According to the theory of industrial organization, market concentration is one of the main factors affecting industrial performance. A large number of empirical studies to determine the relationship between market concentration and industrial performance have been undertaken worldwide. Therefore, we chose industrial scale and market concentration as control variables to avoid bias. Annual industrial output is used to measure industrial scale, and the four-firm concentration ratio in the industry (CR4) is taken as a measure of market concentration.

Owing to sample limitations, we used large industrial enterprises for the period 1996-2011 for regression analyses. Industrial enterprises above a designated size account for the main industrial enterprises in China. Meanwhile, owing to the data acquired are the overall data of industry, we assumed that the attitudes and acceptance levels of all industrial enterprises on environmental regulation are the same. According to data from the Second National Economic Census in 2009, although large industrial enterprises accounted for only $22.4 \%$ of all industrial enterprises up to 2008 , their outputs accounted for more than $90 \%$ of all industrial outputs. Moreover, manufacturing industry accounts for $86.8 \%$ of the main business income of industrial enterprises. Therefore, large industrial enterprises in the manufacturing sector can better reflect the basic situation for all enterprises in the sector. As shown in Table 1, census data on Pro, LP, industrial output, and CR were taken from the China Industrial Economy Statistical Yearbook compiled by the National Bureau of Statistics, some of which were obtained by calculation. Data on environmental regulation were taken from the China Environment Yearbook. Since the government only began to collect data on pollution abatement expenses by industry in 1996, data on pollution control costs were taken as annual industry-specific 
Table 1: Descriptive statistics for the variables.

\begin{tabular}{lcrcrc}
\hline Variable & Observations & Mean & Standard deviation & Max. & Min. \\
\hline Ln Pro $_{i, t}$ & 126 & 3.450 & 0.359 & 2.987 & 0.526 \\
Ln $L P_{i, t}$ & 126 & 12.230 & 0.705 & 14.642 & 9.741 \\
Ln $E R I_{i, t}$ & 126 & 1.754 & 0.308 & 2.761 & 0.503 \\
Ln SIZE $_{i, t}$ & 126 & 8.679 & 0.752 & 11.266 & 7.027 \\
Ln $C R_{i, t}$ & 126 & 4.192 & 0.619 & 5.114 & 1.520 \\
\hline
\end{tabular}

Source: China Statistical Yearbook, China Industrial Economy Statistical Yearbook, China Environment Yearbook.

running costs for wastewater and air pollution treatment from the China Environment Yearbook for 1997-2011.

\subsection{Abbreviations used}

The abbreviations used in this paper were defined hereinafter.

Pro refers to the profit ratio of sales of manufacturing industries. LP is the abbreviation of labor productivity, which reflects the production and economic efficiency of labor input of a company. ERI, SIZE, and CR are the abbreviations of the environmental regulation intensity, industrial scale, and market concentration, respectively.

\subsection{Models}

We used an econometric model [35] to test the sign of the relationship between environmental regulation and manufacturing performance. We performed an analysis of the regression of performance against regulation using panel data in a fixed effects model. The reduced form of the regression model is:

$$
Y_{i, t}=\alpha+\beta X_{i, t}+\gamma R_{i, t}+\varepsilon
$$

where $i$ denotes industry and $t$ refers to time. $Y_{i, t}$ is the performance indicator for industry $i$ in year $t$, $a$ is a constant, $X_{i, t}$ is a vector of control variables that influence industry performance, $R_{i, t}$ is a measure of the stringency of environmental regulation, $\beta$ and $\gamma$ are coefficients for $X_{i, t}$ and $R_{i, t}$, and $\varepsilon$ is an error term.

Based on eqn (1), we can test the effect of environmental regulation on performance according to two models, which are set as eqns (2) and (3). To avoid non-stationarity, we take the logarithm of the variable in the models.

An empirical test of the relationship between stricter environmental regulation and productivity uses the following reduced form equation in our productivity test model:

$$
L n L P_{i, t}=a_{0}+a_{1} \ln E R I_{i, t}+a_{2} \ln S I Z E_{i, t}+a_{3} \ln C R_{i, t}+a_{i, t}
$$

To examine the relationship between stricter environmental regulation and profit, we use the following equation to estimate our profit test model:

$$
L n \operatorname{Pr} o_{i, t}=\beta_{0}+\beta_{1} \ln E R I_{i, t}+\beta_{2} \ln S I Z E_{i, t}+\beta_{3} \ln C R_{i, t}+\beta_{i, t}
$$


where $L n L P_{i t}$ and $L n \operatorname{Pr} o_{i, t}$ are the dependent variables; $E R I_{i, t}, S I Z E_{i, t}$, and $C R_{i, t}$ are explanatory variables; $L P_{i, t}$ is the overall labor productivity, reflecting the efficiency of economic operations in manufacturing industry; $\operatorname{Pr} o_{i, t}$ is the profit margin, which is a proxy for profit levels in manufacturing industry; $E R I_{i, t}$ is the environmental regulation index; $S I Z E_{i, t}$ is the industrial output showing the scale of the manufacturing industry; and $C R_{i, t}$ is the market concentration denoting industrial characteristics. $\alpha_{0}$ and $\beta_{0}$ are constants, $\alpha_{1}, \alpha_{2}, \alpha_{3}, \beta_{1}, \beta_{2}$, and $\beta_{3}$ are coefficients for the explanatory variables, and $\alpha_{i, t}$ and $\beta_{i, t}$ are residual error terms.

\section{RESULTS AND DISCUSSION}

We used Eviews 6.0 to estimate the fixed-effect model. The regression results based on eqns (2) and (3) are presented in Table 2.

The analysis of the fixed effects model show that the results provide evidence to support that the productivity test model has a high degree of goodness of fit statistic that is 0.977 , indicating environmental regulation, industrial scale, market concentration could explain $96 \%$ of the overall labor productivity. The value of DW is 1.986 , close to 2 . Therefore, there exists no correlation, and model set is reasonable. The profit test model has a lower degree of goodness of fit statistic, lower $F$-test statistic, and DW value is 1.604 deviated from 2; this indicates that the there may be auto-correlation phenomena, and the model cannot be explained well.

The results of the regressions support views that there is a positive relationship between environmental regulation and industrial productivity growth. According to the results of the regression on eqn (2), the coefficient for environmental regulation variable is positive and significant at $1 \%$ level. The coefficient is 0.403 , indicating that when environmental regulation is stricter by $1 \%$, industry productivity will increase by $0.403 \%$. The results of the regression on eqn (3) show that the effect of

Table 2: Test results for the relationship between environmental regulation and industrial performance.

\begin{tabular}{lcccc}
\hline & \multicolumn{2}{c}{ Ln LP } & \multicolumn{2}{c}{ Ln Pro } \\
\cline { 2 - 5 } Variable & Coefficient & SE & Coefficient & SE \\
\hline Constant & $2.371^{* * *}(5.931)$ & 0.396 & $2.913^{* * *}(4.220)$ & 0.513 \\
Ln ERI & $0.403^{* * *(4.873)}$ & 0.065 & $0.090(0.744)$ & 0.109 \\
Ln SIZE & $1.004^{* * *(37.21)}$ & 0.032 & $-0.042(-0.819)$ & 0.053 \\
Ln $C R$ & $-0.187^{*}(-2.295)$ & 0.091 & $-0.096(-0.722)$ & 0.147 \\
$R^{2}$ & 0.977 & & 0.673 & \\
AD- $R^{2}$ & 0.969 & & 0.498 & 11.743 \\
$F$-test & 259.463 & & 1.604 & \\
DW & 1.986 & & &
\end{tabular}

Equation estimates

$$
\begin{aligned}
& L n L P_{i, t}=2.371+0.403 \times \ln E R I_{i, t}+1.004 \times \ln S I Z E_{i, t}-0.187 \times \ln C R_{i, t} \\
& L n P R O_{i, t}=2.913+0.090 \times \ln E R I_{i, t}-0.042 \times \ln S I Z E_{i, t}-0.096 \times \ln C R_{i, t}
\end{aligned}
$$

Note: $1 . * * *, * *, *$ denote statistical significance at the $1 \%, 5 \%, 10 \%$ level, respectively; 2 . The values in parentheses are $t$ estimates. 
environmental regulations on the profit margin is not obvious, although the coefficient of environmental regulation variable is positive and insignificant. Hence, the results show that environmental regulations may have facilitation effect and increase the productivity, and therefore improve industrial performance.

The industrial scale would be conductive to industrial productivity. The coefficient for industrialscale variable is positive and significant at $1 \%$ significance level, which indicates that industrial-scale increases by $1 \%$, correspondingly productivity would increase by $1.004 \%$. The coefficient for the industrial scale is negative and insignificant, and its impact on the profit margins will not be considered.

There is a significant negative impact of market concentration on industry productivity. When market concentration increases by $1 \%$, the overall labor productivity decreases by $0.187 \%$. This shows that the high market concentration reduces the company's effective competition within the industry, which is not conducive to industrial productivity. However, the impact of market concentration on profit margins is not significant.

According to the results of the regression on eqn (2), these six industries are equally affected by environmental regulation, industry size, and market concentration, but the intercept between individual equations are different, reflecting individual effects of the six industries, that is, the production rates of the six industries are quite different. The manufacture of paper and paper product, processing of petroleum and coking, and smelting and pressing non-ferrous metals are the three industries having maximum productivity.

It can be seen that environmental regulations can in fact improve the industry performance of manufacturing industry to a certain extent, which is a contrary viewpoint to the traditional views of 'environmental regulation will inevitably reduce industry performance'. Traditional views argues that regulation will led to a decline in industrial performance by means of increasing production costs and crowding out productive investment. The present study supports the Porter Hypothesis. There are a couple of reasons why our empirical results may not be interpreted as support for the traditional views. First, the environmental regulations policies are becoming more rational made by Chinese government, which encourage enterprises to engage in technological innovation. Enterprises take positive measures to manage environments and improve the production craft or product design, to reduce production costs that can make up the cost of environmental regulations, to win innovation compensation, and then promote industry performance. Secondly, the energy utilization efficiency is low in China's manufacturing industry, and environmental regulations can make readjustment of internal allocation of resources, promoting energy efficiency. Simultaneously, environmental regulations will eliminate a number of outdated equipments and inefficient enterprises, and impel firms to strengthen management of the production process in pursuit of higher production efficiency and lower costs, and finally, improve industrial performance; thirdly, with an increase in requirements for environment protection, the ecologically friendly products already approbated by the vast number of consumers gradually. To meet consumer needs, and profit from the market competition, enterprises have enthusiasm and initiative to promote clean production. Therefore, the impact of environmental regulation on environmental-friendly enterprises is little. What's more, building a reputation as an Earth-friendly corporation can achieve a win-win situation for both industrial performance growth and environmental improvement.

\section{CONCLUSIONS AND SUGGESTIONS}

We examined the effect of the stringency of environmental regulations on industry performance using panel data for six typical Chinese manufacturing industries from 1996 to 2011. We found a significant positive relationship between environmental regulations and productivity. If the ERI is increased by $1 \%$, industrial productivity will increase by $0.403 \%$, so environmental regulations have a positive impact on the performance of Chinese manufacturing industries. 
With the expediting of industrialization, industrial pollution is becoming an increasingly serious problem and environmental regulations are being strengthened. To guarantee that environmental regulation policies generate the desired results and do not have a negative impact on industry performance, we present the following recommendations to assure stable economic growth and improve the ecological environment.

Environmental legislation be improved and these laws should be strictly enforced. Although environmental legislation in China remains a work in progress, there are still many problems. The legislation still does not provide strong support for environmental management in terms of integration and manipulation of systems. The legislation should be reformed to quickly resolve the lack of dependable laws and strict enforcement for environmental protection. Our empirical analysis revealed that environmental regulation has a positive impact on industry performance, so appropriate environmental regulation can both enhance industrial performance and protect the environment from any effects of the manufacturing industry.

Marketing of environmental protection in China is necessary. Under a market economy, economic means are more effective than legal and administrative means. Environmental regulation should be enforced through a market economic system based on sustained prices for environmental resources, green taxes, fines for pollution discharges, and an emission trading system. This should motivate enterprises to increase environmental protection through $R \& D$ investment and explore technology for controlling environmental pollution. The specific circumstances of each industry should also be taken into account to select appropriate environmental policy instruments.

Regulated enterprises should actively engage in technological innovation to meet environmental standards and protection targets and gain the economic benefits identified in the Porter Hypothesis. Enterprise is the main contributor to environmental pollution and ecological destruction. Therefore, the government should regulate enterprise to reduce environmental damage. Enterprises should regard environmental regulation as an opportunity to gain an advantage through innovation rather than a factor that adversely affects performance. Firms can engage in circular economics by implementing technological innovation and cleaner production that will both provide environmental benefits and contribute to enhanced productivity.

\section{ACKNOWLEDGEMENTS}

We are grateful to the editors and reviewers for their helpful comments and suggestions. This work was financially supported by the Natural Science Foundation of China (Project 71273258), the Major Bidding Program of the Philosophy Social Science Research Foundation of Jiangsu Province (2010JDXM013), and the Fundamental Research Funds for the Central Universities (2012LWA03).

\section{REFERENCES}

[1] Song, M.L., Song, Y.Q., Yu, H.Y. \& Wang Z.Y., Calculation of China's environmental efficiency and relevant hierarchical cluster analysis from the perspective of regional differences. Mathematical and Computer Modelling, 28(5-6), pp. 1084-1094, 2013. doi: http://dx.doi. org/10.1016/j.mcm.2012.04.003

[2] Song, M.L., Wang, S.H. \& Liu, Q.L., Environmental efficiency evaluation considering the maximization of desirable outputs and its application. Mathematical and Computer Modelling, 58(5-6), pp. 1110-1116, 2012. doi: http://dx.doi.org/10.1016/j.mcm.2011.12.043

[3] Lanoie, P., Patry, M. \& Lajeunesse, R. Environmental regulation and productivity: testing the porter hypothesis. Journal of Productivity Analysis, 30(2), pp. 121-128, 2008. doi: http:// dx.doi.org/10.1007/s11123-008-0108-4

[4] Feichtinger, G., Hartl, R.F., Kort, P.M. \& Veliov, V. M., Environmental policy, the porter hypothesis and the composition of capital: effect of learning and technological progress. Journal 
of Environmental Economics and Management, 50, pp. 434-446, 2005. doi: http://dx.doi. org/10.1016/j.jeem.2004.12.001

[5] Christiansen, G. \& Haveman, R., The contribution of environmental regulations to the slowdown in productivity growth. Journal of Environmental Economics and Management, 8(4), pp. 381-390, 1981. doi: http://dx.doi.org/10.1016/0095-0696(81)90048-6

[6] Jaffe, A.B., Peterson, S.R., Portney, P.R. \& Stavins, R.N., Environmental regulation and the competitiveness of U.S. manufacturing: what does the evidence tell us? Journal of Economic Literature, 33, pp .132-163, 1995.

[7] Dam, L. \& Scholtens, B., Environmental regulation and MNEs location: does CSR matter? Ecological Economics, 67(1), pp. 55-56, 2008. doi: http://dx.doi.org/10.1016/j.ecolecon.2007.11.007

[8] Lee, M., Environmental regulations and market power: the case of the Korean manufacturing industries. Ecological Economics, 68(1-2), pp. 205-209, 2008. doi: http://dx.doi.org/10.1016/j. ecolecon.2008.02.017

[9] Altman, M., When green isn't mean: economic theory and the heuristics of the impact of environmental regulations on competitiveness and opportunity cost. Ecological Economics, 36(1), pp. 31-44, 2001. doi: http://dx.doi.org/10.1016/s0921-8009(00)00211-1

[10] Telle, K. \& Larsson, J., Do environmental regulations hamper productivity growth? How accounting for improvements of plants' environmental performance can change the conclusion. Ecological Economics, 61(2-3), pp. 438-445, 2007. doi: http://dx.doi.org/10.1016/j.ecolecon.2006.03.015

[11] Porter, M.E., America's green strategy. Scientific American, 168(6), pp. 27-28, 1991.

[12] Porter, M.E. \& Toward, C., A new conception of the environment competitiveness relationship. Journal of Economic Perspectives, 9(4), pp. 97-118, 1995. doi: http://dx.doi.org/10.1257/ jep.9.4.97

[13] $\mathrm{Wu}, \mathrm{Y} ., \mathrm{R} \& \mathrm{D}$ and productivity: an empirical study on Chinese manufacturing industry. Economic Research, 11, pp. 60-70, 2006.

[14] Jaffe, A.B. \& Palmer, K., Environmental regulation and innovation: a panel data study. Reviews of Economics and Statistics, 79(4), pp. 610-619, 1997. doi: http://dx.doi. org/10.1162/003465397557196

[15] Murty, M.N. \& Kumar, S., Win-win opportunities and environmental regulation: testing of Porter hypothesis for Indian manufacturing industries. Journal of Environmental Management, 67(2), pp. 139-144, 2003. doi: http://dx.doi.org/10.1016/s0301-4797(02)00203-7

[16] Hamamoto, M., Environmental regulation and the productivity of Japanese manufacturing industries. Resource and Energy Economics, 28(4), pp. 299-312, 2006. doi: http://dx.doi. org/10.1016/j.reseneeco.2005.11.001

[17] Costantini, V. \& Crespi, F., Environmental regulation and the export dynamics of energy technologies. Ecological Economics, 66(2-3), pp. 447-460, 2008. doi: http://dx.doi.org/10.1016/j. ecolecon.2007.10.008

[18] Kammerer, D., The effects of customer benefit and regulation on environmental product innovation: empirical evidence from appliance manufacturers in Germany. Ecological Economics, 68(8-9), pp. 2285-2295, 2009. doi: http://dx.doi.org/10.1016/j.ecolecon.2009.02.016

[19] Testa, F., Iraldo, F. \& Frey, M., The effect of environmental regulation on firms' competitive performance: the case of the building \& construction sector in some EU regions. Journal of Environmental Management, 92(9), pp. 2136-2144, 2011. doi: http://dx.doi.org/10.1016/j.jenvman.2011.03.039

[20] Zhang, C., Liu, H., Bressers, H.T.A. \& Buchanan, K.S., Productivity growth and environmental regulations - accounting for undesirable outputs: analysis of China's thirty provincial regions using the Malmquist-Luenberger index. Ecological Economics, 70(12), pp. 2369-2379, 2011. doi: http://dx.doi.org/10.1016/j.ecolecon.2011.07.019 
[21] Leiter, A.M., Parolini, A. \& Winner, H., Environmental regulation and investment: evidence from European industry data. Ecological Economics, 70(4), pp. 759-770, 2011. doi: http:// dx.doi.org/10.1016/j.ecolecon.2010.11.013

[22] Chakrabarti, S. \& Mitra, N., Economic and environmental impacts of pollution control regulation on small industries: a case study. Ecological Economics, 54(1), pp. 53-66, 2005. doi: http://dx.doi.org/10.1016/j.ecolecon.2004.09.019

[23] Frondel, M., Horbach, J. \& Rennings, K., What triggers environmental management and innovation? Empirical evidence for Germany. Ecological Economics, 66(1), pp. 153-160, 2008. doi: http://dx.doi.org/10.1016/j.ecolecon.2007.08.016

[24] Ulph, A. \& Ulph, D., Trade, strategic innovation and strategic environmental policy: a general analysis. Economics, Energy and Environment, 4, pp. 181-208, 1996. doi: http://dx.doi. org/10.1007/978-94-015-8642-9_10

[25] Shadbegian, R.J. \& Gray, W.B., Pollution abatement expenditures and plant-level productivity: a production function approach. Ecological Economics, 54(2-3), pp. 196-208, 2005. doi: http://dx.doi.org/10.1016/j.ecolecon.2004.12.029

[26] Ji, Y. \& Xu, J., Environmental policy and technical efficiency of production on paper making enterprise (in Chinese). Journal of Beijing Forestry University (Social Science Edition), 5(2), pp. 78-82, 2006.

[27] Hedi, E., Arouri, M., Caporale, G.M., Rault, C., Sova, R. \& Sova, A., Environmental regulation and competitiveness: evidence from Romania. Ecological Economics, 81, pp. 130-139, 2012. doi: http://dx.doi.org/10.1016/j.ecolecon.2012.07.001

[28] Zhou, P., Ang, B.W. \& Poh, K.L., Slacks-based efficiency measures for modeling environmental performance. Ecological Economics, 60(1), pp. 111-118, 2006. doi: http://dx.doi. org/10.1016/j.ecolecon.2005.12.001

[29] Zhang, B., Bi, J., Yuan, Z., Ge, J., Liu, B. \& Bu, M., Why do firms engage in environmental management? An empirical study in China. Journal of Cleaner Production, 16(10), pp. 1036-1045, 2008. doi: http://dx.doi.org/10.1016/j.jclepro.2007.06.016

[30] Triebswetter, U. \& Hitchens, D., The impact of environmental regulation on competitiveness in the German manufacturing industry - a comparison with other countries of the European Union. Journal of Cleaner Production, 13(7), pp. 733-745, 2005. doi: http://dx.doi. org/10.1016/j.jclepro.2004.01.009

[31] He, J. \& Wang, H., Economic structure, development policy and environmental quality: an empirical analysis of environmental Kuznets curves with Chinese municipal data. Ecological Economics, 76, pp. 49-59, 2012. doi: http://dx.doi.org/10.1016/j.ecolecon.2012.01.014

[32] López-Gamero, M.D., Molina-Azorín, J.F. \& Claver-Cortés, E., The potential of environmental regulation to change managerial perception, environmental management, competitiveness and financial performance. Journal of Cleaner Production, 18(10-11), pp. 963-974, 2010. doi: http://dx.doi.org/10.1016/j.jclepro.2010.02.015

[33] El-Zayat, H., Ibraheem, G. \& Kandil, S., The response of industry to environmental regulations in Alexandria, Egypt. Journal of Environmental Management, 79(2), pp. 207-214, 2006. doi: http://dx.doi.org/10.1016/j.jenvman.2005.07.002

[34] Zhao, H., The impact of environmental regulation on industrial technological innovation - an empirical research based on the panel data from China (in Chinese). Industrial Economics Research, (3), pp. 35-40, 2008.

[35] Gray, W.B. \& Shadbegian, R.J., Plant vintage, technology, and environmental regulation. Journal of Environmental Economics and Management, 46(3), pp. 384-402, 2003 doi: http:// dx.doi.org/10.1016/s0095-0696(03)00031-7 